\title{
ENTREPRENEURSHIP AND INNOVATION TOWARDS RURAL DEVELOPMENT EVIDENCE FROM A PERIPHERAL AREA IN PORTUGAL
}

\author{
Lúcia Pato ${ }^{1}$
}

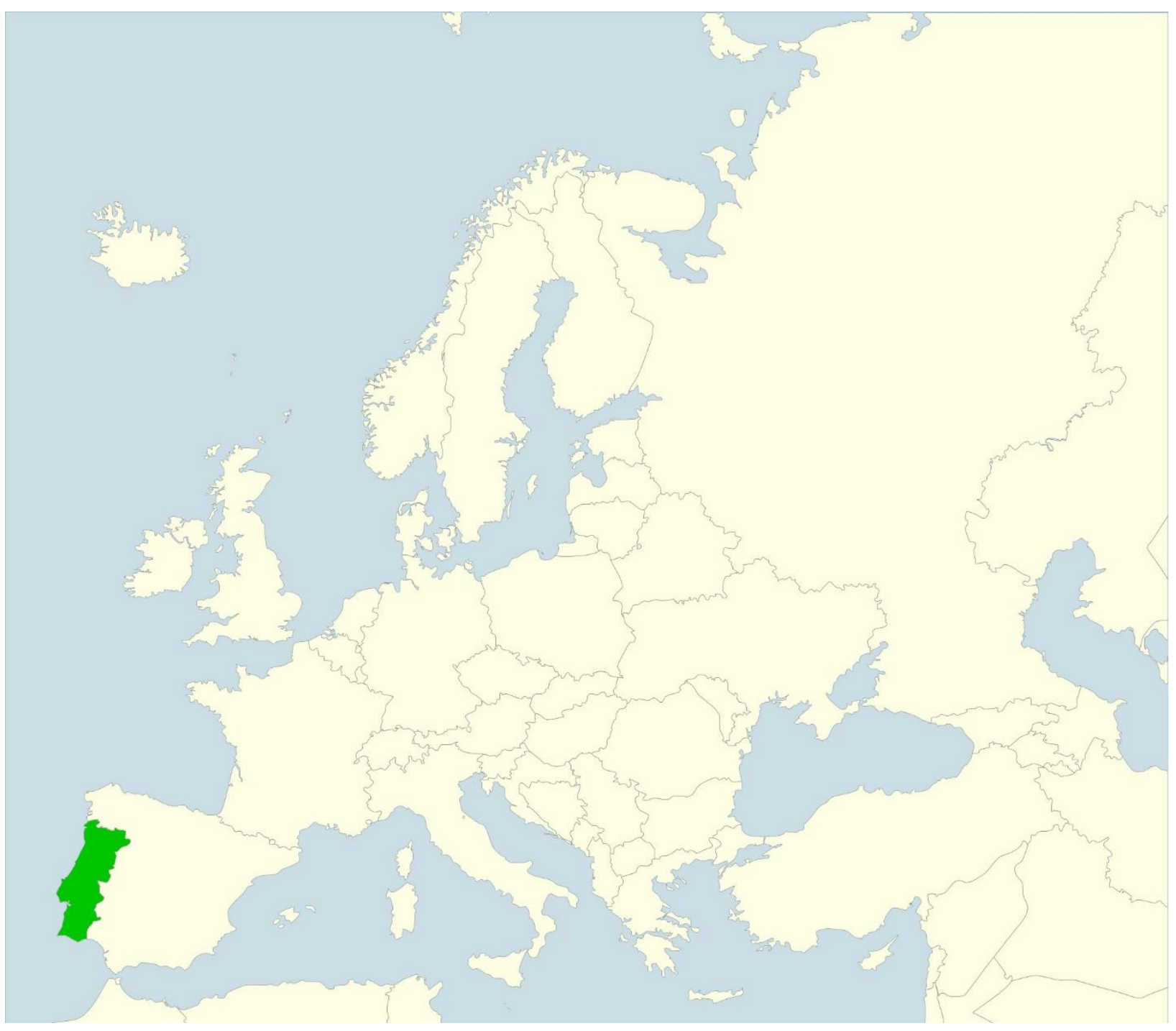

${ }^{1}$ Maria Lúcia Pato, PhD., CERNAS-IPV Research Centre, Polytechnic Institute of Viseu, Portugal, ORCID: 00000002-2286-4155, e-mail: mljesus@esav.ipv.pt 
Abstract: Based on an exploratory research, this study highlights the role of pure rural entrepreneurship towards rural development of an inland and mountainous area of Portugal-Montemuro. Thanks to the Institute of Cultural Affairs and the energy of the rural communities, some people of the rural area have been stimulated thirty years ago to develop endogenous, entrepreneurial and innovative initiatives in the countryside. The benefits of all these rural entrepreneurial and endogenous initiatives are visible nowadays. Some villages of the rural area have more people, socio-economic dynamics were revitalized, and some job opportunities were created. Therefore, in a context of depopulation and crisis of peripheral and interior areas, our study demonstrates that rural entrepreneurship and innovation based on endogenous resources are key for the welfare of the rural society.

Keywords: Rural Entrepreneurship; Innovation; Endogenous resources; Rural development, Montemuro Area

\section{Introduction}

The so-called less favoured areas, mostly inland and mountain, face similar challenges that call for innovative answers (Fink, Lang, \& Richter, 2017; Pato \& Teixeira, 2016). Comparative to urban centres such areas suffer from low economic productivity and lack of jobs for people (Fink et al., 2017). It is not surprising, therefore, that depopulation remains the dominant demographic trend, especially amongst the younger and economically active groups apart from an older and aging population (Ecorys, 2010). Many of these areas are in danger of abandonment because they have low productivity of the natural environment (EC, 2013).

In this context, on the one hand, great hope is placed in rural entrepreneurship. Indeed, rural entrepreneurship have emerged as one of the most potential tools for inducing the development of rural areas (Dinis, 2006; Korsgaard, Müller, \& Tanvig, 2015; Pato \& Teixeira, 2016, 2018). It is even more important, how much fewer opportunities, people in these areas have. The concept of rural entrepreneurship suggests that it is a form of endogenous entrepreneurship, which has to do with the social-spatial dimension of the rural and adds something-extra to rural communities (Korsgaard, Müller, et al., 2015). On the other hand, due to globalization processes which introduce new networks of global interconnectivity (Woods \& McDonagh, 2011), a lot of entrepreneurial opportunities have emerged in rural areas, including an increased demand for recreational and rural amenities (Pato \& Teixeira, 2016; Stathopoulou, Psaltopoulos, \& Skuras, 2004). In fact, globalization is a general influence in restructuring rural areas in Europe and elsewhere, and as such presents both challenges and opportunities for rural development (Woods \& McDonagh, 2011).

Being aware of this reality, the European Union (EU) considers rural entrepreneurship as a key component of the EU's Europe 2020 strategy for smart, sustainable and inclusive growth in Europe's rural areas (Pato, 2016; Strano et al., 2012).

Despite keen interest in rural entrepreneurship and the emergence of interesting surveys on the issue (McElwee \& Smith, 2014; Pato \& Teixeira, 2016), with some exceptions (e.g. Korsgaard, Müller, et al., 2015; Pato \& Teixeira, 2018), very few studies look into the nature, characteristics and benefits of "pure rural entrepreneurship", mainly in peripheral areas. Therefore, this study focuses on the role of rural entrepreneurship towards the development of an inland and mountainous area of Portugal-Montemuro and the key of rural and social innovation in the process. Thanks to the initiative of the Institute of Cultural Affairs (ICA) who was in the area more than thirty years ago, some people have been stimulated to develop endogenous, entrepreneurial and innovative initiatives in their rural communities.

Using a case study approach, the work uses the information collected by interviews done to the most notorious entrepreneurs of the region, who maintain the initiatives survive. 
The benefits of all these rural entrepreneurial and endogenous initiatives are visible nowadays in Montemuro. Some villages have more people, socio-economic dynamics are revitalized, some job opportunities are created for local people and the name of Montemuro is communicated nationally and internationally.

The paper consists of four sections after the introduction. In literature review, we explore the meaning of rural entrepreneurship and the importance of innovation in rural entrepreneurship. After this, section 3 presents the case study and methodological procedures. The results of the study and its discussion are presented in Section 4. Finally in the end section, the main conclusions, limitations, as well as the study's contribution to knowledge and practice, are presented.

\section{The meaning of rural entrepreneurship and innovation}

\subsection{Rural entrepreneurship}

In a context of scarce human and financial resources typical of rural areas (Pato \& Kastenholz, 2017), entrepreneurship is nowadays considered a vital mechanism in creating economic activity and growth in the rural space, and therefore a mechanism towards regional and rural development (Baumgartner, Pütz, \& Seidl, 2013; Baumgartner, Schulz, \& Seidl, 2013; Korsgaard, Ferguson, \& Gaddefors, 2015; OECD, 2006; Pato \& Teixeira, 2018). Additionally, these areas can be places of diverse entrepreneurial activities both within traditional-based activities and non-traditional industries, due to a wide range of valuable and place-based or localised resources.

The seminal work of Wortman Jr. (1990) refers to rural entrepreneurship as "the creation of a new organization that introduces a new product, serves or creates a new market, or utilizes a new technology in a rural environment" (Wortman Jr., 1990, p. 330). This concept follows the concept of innovation presented by Schumpeter (1934), but adds a new variable - the rural space. However, this study, does not go much further in terms of the implications in the rural economy and space. Indeed, almost thirty years since the publication of Wortman's pionnering work (1990), rural entrepreneurship continues to be observed as the creation and development of enterprises in rural areas (see Deller, Kures, \& Conroy, 2019; Yu \& Artz, 2018). Moreover, rural enterprises are often defined as those (enterprises) located in the countryside with the entrepreneurial potential of generating rural progress (Chege \& Wang, 2020).

However, while ones enterprises are only located in rural areas ('entrepreneurship in rural areas'), others are 'pure' forms of rural entrepreneurship ('rural entrepreneurship') (Pato \& Teixeira, 2018). The problem is that often studies do not recognize the increasing diversity of entrepreneurial activities in rural areas, and diminish the fact that rural entrepreneurial activities can exist in the rural space in a diversity of forms (Korsgaard, Müller, et al., 2015). In 'entrepreneurship in rural areas', rural attributes might merely describe the rural environment in which entrepreneurial activities take place, while in 'rural entrepreneurship' rural attributes might shape the entrepreneurial process itself (Baumgartner, Schulz, et al., 2013). Here, the entrepreneurs are not simply present in a spatial rural context-they are embedded in the place, in the sense that they have a strong understanding of the resources in the local rural context, and how to access these resources in a better and sustainable way (Korsgaard, Ferguson, et al., 2015). In this sense, it is fundamental to recognise, that while several ventures in the rural are really rural, since they present 'pure rural characteristics', others only appear more or less casual in the rural space (Baumgartner, Schulz, et al., 2013; Pato \& Teixeira, 2016, 2018).

'Rural entrepreneurship' as it is conceptualised here, involves particular engagement with the place and is rooted in its economic and social environment through resource use (Korsgaard, Müller, et al., 2015). Based on this concept, rural entrepreneurship involves new combinations of endogenous resources that creates value for the entrepreneur and the rural community (Korsgaard, Müller, et al., 2015). Furthermore, rural entrepreneurship implies straightaway the participation of local people and their knowledge in the process of entrepreneurship. For this reason, this type of entrepreneurship is connected with the rural place and its material and immaterial resources. Rural entrepreneurship cannot be located in 
a different place without losing all or part of its nature, due precisely to local embeddedness (Korsgaard, Müller, et al., 2015; Müller \& Korsgaard, 2018).

Thus, it is understandable that not all the entrepreneurs who operate and manage a venture in rural areas are rural entrepreneurs in a strict sense (Pato \& Teixeira, 2018). A rural entrepreneur is someone who is embedded in the rural space (Akgün, Nijkamp, Baycan, \& Brons, 2010), and make use of the strong local networks and sense of community (Müller \& Korsgaard, 2018). In turn, this explains (at least partially) that many rural entrepreneurs are less motivated (mainly) by monetary benefits, being motives tightly connected to the well-being of the place and community (Korsgaard, Müller, et al., 2015).

\subsection{Rural Innovation}

In rural areas, the shift from sectoral to territorial rural development strategies as a result of socioeconomic structural change resulted in a stronger focus on neoendogeneous strategies and practises (Labianca \& Valverde, 2019; Neumeier, 2012). The fundamental issue in these strategies is no longer the capacity of the region to attract foreign enterprises but its capacity to internally generate the conditions of transformation of its own productive structures (Dinis, 2006). Furthermore, if the area is to benefit from the economic exploitation of its own resources, it must be done by people that belong to the territory (Dinis, 2006) and by mobilising actors where participation not only concentrate on sustaining traditions but may led to social, economic and cultural renewal (Neumeier, 2012). It is principally the development of sustainable structures and organizations that on the one hand enable innovation and creativity in the rural territory and on the other hand promote the rural space outdoor in a way that these entrepreneurs become ambassadors (Pato \& Teixeira, 2018). In fact, with the emphasis being placed upon endogenous development coupled with the need for alternative economic practices (due to the crisis in agrarian activities), a significant body of literature has explored the emergence of rural innovation as a new economic trajectory for rural areas. The suggestion is that engaging in entrepreneurial behaviours and creating rural business holds the key to their sustainable growth (Alsos, Ljunggren, \& Hytti, 2013; Fhlatharta \& Farrell, 2017). In this context, it is not surprising that the concept (rural innovation) has become a key facet within political discourse (Fhlatharta \& Farrell, 2017; Navarro et al., 2018).

Innovation-as an ingredient that promotes differentiation, change and/or exclusivity-will create a dominant power in the market, allowing superior and considerable advantages for rural business (Dinis, 2006; Tunney, 2015). In fact, born from the stems of traditional innovation theory (see Schumpeter, 1934), Mahroum et al. (2007, p. 6) observe rural innovation as the introduction of something new (a novel change) to economic or social life in rural areas which adds new economic or social value to rural life. In this sense, it is understandable that the process of rural innovation should involve a plurality of actors, the active participation of local stakeholders and collaborative actions (Brunori et al., 2008; Labianca, De Rubertis, Belliggiano, Salento, \& Navarro, 2020). Therefore, in our opinion, rural innovation and social innovation are two interconnected concepts. As referred by Neumeier $(2012,2017)$ social innovation deals with changes of attitudes, behaviour or perceptions of a group of people joined in a network of aligned interests that lead to some kind of tangible improvement for the actors involved or even beyond. In other words, it adds new economic or social value to the rural community (the purpose of rural innovation). It is divided into the 3 following phases (Neumeier, 2012, 2017): problematization (an individual or an initial group identifies a problem and a need and seeks a solution); expression of interest (other actors are added, seeing an advantage in this cooperation); delineation and coordination (a new collaborative form and development strategy is born).

As aforementioned, Joseph Schumpeter (1934) was one of the first to address rural innovation, although indirectly. In his theory of 'creative destruction' he observed innovation as the: i) introduction of a new good; ii) introduction of a new method of production; iii) open a new market; iv) utilisation of a new source of supply; v) creation of some new organisational forms in the industry (Schumpeter, 1934). Although nowadays researchers conceptualize innovation in a variety of ways, the Schumpeter's idea of innovation remains valid and influences various 
works (see Dinis, 2006; Madureira, Gamito, Ferreira, \& Portela, 2013; OECD \& Eurostat, 2005; OECD/Eurostat, 2018; Rosenbusch, Brinckmann, \& Bausch, 2011). For instance, Navarro et al. (2018, p. 109) see it as significant changes to improve the product, process, marketing or the organization to get better results from a company or a territory. If in other times these changes are applied through new knowledge and technologies (OECD \& Eurostat, 2005) the contemporary form of innovation has begun to move beyond technological advancement and is now more frequently viewed as a process of improvement and change (Fhlatharta \& Farrell, 2017, p. 16).

\section{Case study presentation and methodological procedure}

\subsection{A brief note of less favoured areas and the case study presentation}

As in many rural areas in Europe, the Portuguese Countryside is often confronted with poor viability of farms (Ramos, 2013), few jobs opportunities and distance from markets and services. Therefore, mainly in remote and peripheral rural areas of Portugal, the outmigration of young, more highly educated people, a declining and ageing population is a constant.

To try to combat such trends and bear in mind the sustainable rural development of such areas, the European Commission (EC) has earmarked so-called less-favoured areas (LFAs) in its policy framework for special assistance. Namely, the Regulation EC' 1257/99 has integrated in LFAs the mountain areas (article 18), other less-favoured areas (article 19), and areas affected by specific handicaps (article 20). Altogether $86.6 \%$ of Portugal's agricultural area falls into LFAs, of which $30.8 \%$ are in mountainous areas (Ramos, 2013).

According to the Portuguese recent legislation (Portaria 5/2019), all Montemuro area, which encompasses five municipalities of the north-west of Portugal (Arouca, Cinfães, Resende, Castro Daire and Lamego) is classified as a less favoured areas, specifically a mountain area.

Castro Daire municipality, where examples of pure rural entrepreneurial initiatives take place, is a municipality with 16 parishes and a population density of only 40.4 inhabitants $/ \mathrm{km}^{2}$ (INE, 2012). In this municipality, traditionally, familiar agriculture has been the main economic activity. As many other rural and remote municipalities of the Portuguese countryside, Castro Daire suffers with the declining and ageing of its population.

This fact influences the availability of educational and other public services and the quality and density of many infrastructure, which are scarce. Problems are also evident in terms of employment opportunities and a decline in agriculture. Moreover, the unemployment rate is high (near of $11 \%$ ) and affects mostly the female population, with an unemployment rate of $14 \%$ (INE, 2012).

Despite these constraints, thanks to the power of population and endogenous resources, the municipality has some of the most rich pure rural entrepreneurship initiatives of the mountain area and (maybe of) the country. They operate in the manufacture of fashion clothes based on endogenous resources ("Capuchinhas do Montemuro", "Lançadeiras do Picão" and "Cooperativa de Artesãos do Montemuro"), local and traditional culture ("Teatro Regional da Serra do Montemuro") and production of aromatic and medicinal plants in an organic way (“Ervital”).

\subsection{Methodological Procedure}

This work uses a case study approach. Case studies, in general, are the preferred way to do research when "how" or "why" questions are being posed, and when the focus is on a contemporary phenomenon within some real life context (Yin, 2009).

The case study implies the use of different information sources. Besides documental analysis, field observation and semi-structured interviews, were used. The interviews targeted three local group of entrepreneurs/actors of the region ("Capuchinhas do Montemuro", "Teatro Regional do Montemuro" and "Ervital"). These case studies were chosen because on the one hand they are 
all examples of pure rural initiatives and on the other hand, they are the most notorious initiatives in the area (Pato, Breda, \& Figueiredo, 2015).

The guidelines for the interviews were based on the literature review concerning rural entrepreneurship and innovation. In order to identify the main discourse of the rural entrepreneurs, the interviews were tape-recorded, transcribed and subject to content analysis. In fact, the objective in this (qualitative) content analysis is to systematically transform a volume of text into an organised and concise summary of key results (Erlingsson \& Brysiewicz, 2017). More precisely, the initial step began with the reading of each interview to get a sense of the whole idea, i.e., to gain a general understanding of what the entrepreneurs were talking about. Then, the texts were divided into smaller parts or units, being these ones associated to labels: rural entrepreneurship, rural innovation and social innovation, and so on. The interviewees are identified in the next section with the letter $E$ (entrepreneur), followed by the interview number.

In the analysis of these entrepreneurial cases, special attention was given to the stages of social innovation suggested by Neumeier $(2012,2017)$ : problematisation, expression of interest and delineation and coordination.

\section{Results and discussion}

\subsection{Results}

Taking advantage of endogenous resources, local and traditional knowledge of some people of Castro Daire municipality, approximately four decades ago, have been stimulated to improve their life conditions. The stimulus was given by ICA, which was established in the area of Montemuro in the eighties. This international association called volunteers from all over the world to work in poor geographic areas. Its purpose was to alleviate the needs of rural communities, characterised by subsistence farming, high male migration, female unemployment and lack of housing, sanitation and health (Rocha, 2015).

Specifically, in Castro Daire municipality, ICA was able to i) gather some women to work together in the production of fashion and home textile products through training courses; ii) organize some men to work in theater festivals embedded in local traditions and; iii) encourage the production of biological and therefore more qualitative farming products.

A group of women artisans in Campo Benfeito village (Gosende parish) was one of the first rural entrepreneurship initiative to appear. Their initiative began in 1985, as a result of the effort of the aforementioned Institute, which, following a sequence of training courses, was able to prepare this group of women to work together in the creation of home textile and fashion weaving pieces, based on local traditions and materials-flax, wool and burel (Dinis, 2006; Pato et al., 2015). In 1987, these women officially created the firm with the designation "Capuchinhas do Montemuro", a brand inspired by the "Capucha" that is the traditional brown cape of the mountain area of Montemuro. These are resilient women with a strong desire to live in their rural communities:

"The idea of Capuchins came up here because we wanted to live here, we were born here, the land is poor, it doesn't give much, but we wanted to do anything that would let us live and earn money here, without needing to go outside" (E1).

Some years later, due to some fiscal issues, these women/local actors have converted the firm into a cooperative with the same name ("Capuchinhas do Montemuro"). Presently, the cooperative works with four women, all from the village. They create original and innovative pieces of elegant and fashionable clothing, but also pieces with a strong identity of the Montemuro area. Nowadays, these women have inclusively the support of a stylist who helps them in the confection of these original products: 
"We are careful to always have a stylist every year to have innovation and not to let this work die (...) we want to keep it until we can work, and if it is still possible to continue with our followers (...)" (E1).

Because the work of "Capuchinhas" is a noticeable example of creativity and resilience, in 2007, they inclusively received the international prize for Women's Creativity in Rural Life, created by the Women's World Summit Foundation (WWSF), with headquarters in Geneva (Switzerland).

Nowadays, the benefits of such rural entrepreneurship are clear-socio-economic dynamics were revitalized and the community have pride in this initiative: "The people here in the village really like our existence, they take great pride in our work (...) they say that, without us, currently the village would have disappeared" (E1).

Another successful rural entrepreneurship initiative is also located in Campo Benfeito village"Teatro Regional da Serra do Montemuro". The theatre company began its activity in the nineties through the contact of an English volunteer of ICA with academic training in theatre studies and the young men of the village. Like the above example, this group of actors wanted to do something different and contribute to the dynamization of the community:

"We worked the moment and the possibility that we were doing something different and dreaming. That was one of the reasons that led us to participate and to insist (...) (...) the community grasped the project so well that it was the need that arose, immediately afterwards, to give" (E2).

Between 1990 and 1995, based on a work around local stories, popular culture and local heritage, the young men/actors of Campo Benfeito village in articulation with ICA present a series of spectacles. Above all, what distinguishes the company from so many other in the country, is its rural character:

"We are from here, we try to build a set of stories very based on this universe, in this rural world (...) this makes the difference in relation to other projects, we can carry our traditions (...) look a little bit at this side of rurality of the area" (E2).

In 1995, "Lobo-Wolf" premiered in England and presented in the International Theatre Festival in Tondela (a nearby city in Portugal that have a tradition in theatre festivals), allowing the rural company, until then with more amateur features, "to jump". Indeed, faced with the excellent criticism, the company decided to seek help in the "Secretary of State of National Culture" in Portugal.

"(...) in 95 "Lobo Wolf" show was born-it was the first show at a professional level, and because it had an international dimension and an extraordinary impact, some institutions, such as the Association of Cultural and Recreational Association of Tondela (ACERT) told us to seek help from the national Portuguese state" (E2).

Nowadays, it works with six people, mainly from the village. They produce several theatre festivals throughout the year. "Altitudes" festival is perhaps the well-known festival of the company, since it gathers to the village in one week (in general in August) several national and international companies, as well as thousands of people that come to the village to celebrate the music and the popular culture.

As the above example, the impacts of such initiative are clear in terms of the community' socioeconomic revitalization and maintenance of local population:

"(...) if there was no "Teatro da Serra do Montemuro" and "Capuchinhas", the village would not exist at this time (...) (...) since about 15 years ago, people have not left from here, quite the contrary. Of course, we are talking on a very small scale because the village has few inhabitants, but we even have two young couples who have returned to the community (E2)".

"(...) Nowadays in Campo Benfeito we live well (...), with the difficulties that everyone has, but there are meetings, there is a space for socializing... the Montemuro theater continues to have a regular program, whether it be through the reception of schools, through the shows that are being made here or abroad" (E2). 
In the neighbouring parish, namely in Mezio village, is located another successful and innovative example of rural entrepreneurship - "Ervital". The firm, which has an American partner, who also came to the region through ICA, began its activity in the nineties. Having been pioneer in Portugal in the production of aromatic and medicinal plants in an organic way, the company has been evolving based on a principle of social and environmental sustainability. The presence of endogenous resources-local vegetable plants-the environmental local conditions, as well as the preservation of the region allowed to obtain products of excellent quality: (...) "the context, the place and its altitude help the production quality..." (E3). As in the above examples, the entrepreneur also said that the village struggled to keep the population:

"Here, in the case of Mezio, we have kept the population, unlike other villages and other
regions which has lost population (...) Ervital has made a contribution. If we extend this to
other villages-in Campo Benfeito village we have "Capuchinhas". Moreover, there is also
a context that help to explain this-here, we have a tradition that those who work outside
return at least at the weekend to the village. Most people keep their family here and
continue to have some farms" (E3).

The dynamics of this rural entrepreneurship initiative are also evident in the creation of local employment (at the moment, it has 5 local employees and 5 trainees).

But the story of rural entrepreneurship in the rural area does not finish here. Although with less expression than the mentioned examples, in a nearby location, other successful examples were set up. Indeed, thanks to the energy created by ICA in the eighties and nineties (Dinis, 2006), another group of local women/actors: "Lançadeiras do Picão" (in Picão village) try to keep the cultural heritage of their communities alive, nowadays producing several pieces of wool and flax, also with a strong identity of the area of Montemuro. Also, another group of people/actors, "Associação Etnográfica do Montemuro" and "Cooperativa de Artesãos do Montemuro", in Mezio village, based on the production of innovative and original pieces, have contributed to the sustainable rural development of the area. In this last initiative, we can see pottery (black clay), basketry in straw and bramble, weaving rags, bed covers in wool and burel ("capuchas" and other garments), linen and others.

\subsection{Discussion}

Rural entrepreneurship and rural/social innovation involve, as demonstrated in all the cases described above, the use of place-based or localized rural resources. It is clear that this type of entrepreneurship creates value not solely for the entrepreneur(s), but also for the rural place (Korsgaard, Müller, et al., 2015; Pato \& Teixeira, 2018). On the one hand it reflects the concept of social innovation, emphasized by Neumeier $(2012,2017)$; on the other hand it reflects the embeddedness of the rural entrepreneurs in the rural place (Korsgaard, Müller, et al., 2015).

Specifically, with the purpose to improve life conditions in rural communities, an initial group of actors inspired by ICA decided to change their behaviour and attitudes and participate in diverse rural entrepreneurial initiatives (problematization). Afterwards, through the contact between ICA and these initial local actors, other actors joined the core group of actors as they saw some type of advantage from themselves in participation (expression of interest). In fact, all the initiatives presented here have the support of the local people and gradually involved (directly or indirectly) more and more actors - for instance, for communication and marketing and so on. Skills, knowledge and knowhow are improved between the participating groups of actors, and mutual learning occurs in these groups (Delineation and co-ordination) and new forms of collaborative action got formed. Thus, this type of entrepreneurship cannot be relocated elsewhere without losing part or all of its key value proposition due to its close engagement with the rural place (Müller \& Korsgaard, 2014).

The following (Navarro et al., 2018) rural innovation are expressed in this study in four dimensions: 
Product innovation: resulting from the association of endogenous resources (e.g. flax and wool) and traditional techniques with new and fashion designs. This is the case of "Capuchinhas do Montemuro".

Process innovation: resulting from the implementation of a new system of production or delivery method. This includes significant changes in techniques, equipment or software. This type of innovation is clear in the case of "Ervital", pioneered in Portugal in using digital platforms to place orders. Presently, also "Capuchinhas do Montemuro" use this type of digital platforms to communicate with their customers.

Organizational innovation: as the new engagements and local relationships established based on economic, social and cultural relationships (in all the initiatives presented), but also the regional, national and international relationships with other entities and socio-cultural institutions (Dinis, 2006). This is indubitably the case of "Teatro Regional da Serra do Montemuro".

Marketing innovation: resulting from the application of new marketing methods and changes if product (for instance, packaging), price, delivery and promotion. This is the case of all initiatives presented here.

All these kinds of innovation make the entrepreneurs and its products/services presented in this study ambassadors of their places (Pato \& Teixeira, 2018).

\section{Conclusions}

Drawing on a case study developed in Montemuro area, the present paper makes some important contributions to knowledge and practise. First, it underlines the real contribution of rural and endogenous entrepreneurship and innovation, highlighting the role of the community in all the process. Put in a different way, the socio-spatial context matters (Balfour, Fortunato, \& Alter, 2018). Indeed, in a territory with clear symptoms of interiority and with scarce material and financial resources, local people became active members of the local rural communities, creating projects that gave life and revitalized all the space, thus reinforcing the concept of social innovation. The impacts are visible immediately in the preservation of the cultural heritage of the communities, creation of local employment, the leverage of population settling and welfare of the local society.

Secondly, in terms of practical implications, we argue that for the progress of all these entrepreneurial initiatives, governmental and other regional entities, should conduct the creation of a culture of entrepreneurship based on local and endogenous resources and support them in several aspects (training, financial, etc). In this perspective, on the one hand our results suggest that 'animatorship', that is, encouraging individuals to be entrepreneurial and sponsoring, channelling or promoting their entrepreneurial spirit, is essential (McElwee, Smith, \& Somerville, 2018; Pato \& Teixeira, 2019). On the other hand, our results also suggest that, there is a need for new rural economic agendas, which emphasize what is genuine and typical in a given region and country (Pato \& Teixeira, 2018).

The study naturally has its limitations, such as those given by time constraints, making it difficult to interview more entrepreneurs and other stakeholders, such as the political and institutional authorities. Still, we recognize the relevance of a systematic and deeper qualitative study involving other stakeholders that would allow us to understand in greater depth the potential of rural and endogenous entrepreneurship towards rural development and its limitations/constraints.

Therefore, it terms of future research, it would be interesting to research the political and institutional support given to these initiatives.

\section{Acknowledgments:}

This work is funded by National Funds through the FCT - Foundation for Science and Technology, I. P., within the scope of the project Ref ${ }^{a}$ UIDB/00681/2020. Furthermore, we would 
like to thank the CERNAS Research Centre and the Polytechnic Institute of Viseu for their support.

\section{Academic references}

[1] Akgün, A. A., Nijkamp, P., Baycan, T. \& Brons, M. (2010). Embeddedness of entrepreneurs in rural areas: A comparative rough set data analysis. Tijdschrift voor Economische en Sociale Geografie, 101(5), 538-553. DOI: 10.1111/j.1467-9663.2010.00630.x.

[2] Alsos, G. A., Ljunggren, E. \& Hytti, U. (2013). Gender and innovation: state of the art and a research agenda. International Journal of Gender and Entrepreneurship \& Regional Development, 5(3), 236-256. DOI: 10.1108/IJGE-06-2013-0049.

[3] Balfour, B., Fortunato, M. W.-P. \& Alter, T. R. (2018). The creative fire: An interactional framework for rural arts-based development. Journal of Rural Studies, 63, 229-239. DOI: 10.1016/j.jrurstud.2016.11.002.

[4] Baumgartner, D., Pütz, M. \& Seidl, I. (2013). What Kind of Entrepreneurship Drives Regional Development in European Non-Core Regions? A Literature Review on Empirical Entrepreneurship Research. European Planning Studies, 21(8), 1095-1127. DOI: 10.1080/09654313.2012.722937.

[5] Baumgartner, D., Schulz, T. \& Seidl, I. (2013). Quantifying entrepreneurship and its impact on local economic performance: A spatial assessment in rural Switzerland. Entrepreneurship \& Regional Development, 25(3-4), 222-250. DOI: $10.1080 / 08985626.2012 .710266$.

[6] Brunori, G., Rand, S., Proost, J., Barjolle, D., Granberg, L. \& Dockes, A.-C. (2008). Towards a conceptual framework for agricultural and rural policies. IN-SIGHT Project Strengthening Innovation Processes for Growth and Development. Retrieved from: https://pdfs.semanticscholar.org/543a/2624f100d9b65fdcf0f13ef66c4359c8d8a6.pdf?_ga=2 .84831580.472413735.1593277413-878361732.1593277413.

[7] Chege, S. M. \& Wang, D. (2020). The impact of entrepreneurs' environmental analysis strategy on organizational performance (forthcoming). Journal of Rural Studies. DOI: 10.1016/j.jrurstud.2020.04.008.

[8] Deller, S., Kures, M. \& Conroy, T. (2019). Rural entrepreneurship and migration. Journal of Rural Studies, 66, 30-42. DOI: 10.1016/j.jrurstud.2019.01.026.

[9] Dinis, A. (2006). Marketing and innovation: Useful tools for competitiveness in rural and peripheral areas. European Planning Studies, 14(1), 9-22. DOI: 10.1080/09654310500339083.

[10] Erlingsson, C. \& Brysiewicz, P. (2017). A hands-on guide to doing content analysis. African Journal of Emergency Medicine, 7(3), 93-99. DOI: 10.1016/j.afjem.2017.08.001.

[11] Fhlatharta, A. M. N. \& Farrell, M. (2017). Unravelling the strands of 'patriarchy' in rural innovation: A study of female innovators and their contribution to rural Connemara. Journal of Rural Studies, 54, 15-27. DOI: 10.1016/j.jrurstud.2017.05.002.

[12] Fink, M., Lang, R. \& Richter, R. (2017). Social Entrepreneurship in Marginalised Rural Europe: Towards Evidence-Based Policy for Enhanced Social Innovation. Regions Magazine, 306(1), 6-10. DOI: 10.1080/13673882.2017.11878963.

[13] Korsgaard, S., Ferguson, R. \& Gaddefors, J. (2015). The best of both worlds: how rural entrepreneurs use placial embeddedness and strategic networks to create opportunities. Entrepreneurship and Regional Development, 27(9-10), 574-598. DOI: 10.1080/08985626.2015.1085100. 
[14] Korsgaard, S., Müller, S. \& Tanvig, H. W. (2015). Rural entrepreneurship or entrepreneurship in the rural - between place and space. International Journal of Entrepreneurial Behavior \& Research, 21(1), 5-26. DOI: 10.1108/IJEBR-11-2013-0205.

[15] Labianca, M., De Rubertis, S., Belliggiano, A., Salento, A. \& Navarro, F. (2020). Social Innovation, Territorial Capital and LEADER Experiences in Andalusia (Spain) and in Molise (Italy). In Cejudo, E. \& Navarro, F., eds., Neoendogenous Development in European Rural Areas (pp. 111-131). Cham: Springer.

[16] Labianca, M. \& Valverde, F. N. (2019). Depopulation and aging in rural areas in the European Union: practices starting from the LEADER approach. In Cejudo, E. \& Navarro, F., eds., Despoblación y transformaciones sociodemográficas de los territorios rurales: Ios casos de España, Italia y Francia (pp. 223-252): Lecce: Universitá Del Salento.

[17] Madureira, L., Gamito, T. M., Ferreira, D. \& Portela, J. (2013). Inovação em Portugal Rural Detetar, Medir e Valorizar. Cascais: Princípia Editora.

[18] Mahroum, S., Atterton, J., Ward, N., Williams, A. M., Naylor, R., Hindle, R. \& Rowe, F. (2007). Rural innovation. London: National Endowment for Science, Technology and the Arts.

[19] McElwee, G. \& Smith, R. (2014). Researching rural enterprise. In Fayolle, A., ed., Handbook of Research on Entrepreneurship (pp. 307-334). Cheltenham: Edward Elgar.

[20] McElwee, G., Smith, R. \& Somerville, P. (2018). Conceptualising Animation in Rural Communities: The Village SOS Case. Entrepreneurship and Regional Development, 30(12), 173-198. DOI: 10.1080/08985626.2017.1401122.

[21] Müller, S. \& Korsgaard, S. (2014). (Re)Sources of opportunities - The Role of Spatial Context for Entrepreneurship. In Academy of Management Annual Meeting Proceedings. Briarcliff Manor, NY: Academy of Management.

[22] Müller, S. \& Korsgaard, S. (2018). Resources and bridging: the role of spatial context in rural entrepreneurship. Entrepreneurship \& Regional Development, 30(1-2), 224-255. DOI: 10.1080/08985626.2017.1402092.

[23] Navarro, F., Labianca, M., Cejudo, E., Rubertis, S. D., Salento, A., Maroto, J. C. \& Belliggiano, A. (2018). Interpretations of innovation in rural development. The cases of Leader projects in Lecce (Italy) and Granada (Spain) in 2007-2013 period. European Countryside 10(1), 107-126. DOI: 10.2478/euco-2018-0007.

[24] Neumeier, S. (2012). Why do Social Innovations in Rural Development Matter and Should They be Considered More Seriously in Rural Development Research? - Proposal for a Stronger Focus on Social Innovations in Rural Development Research. Sociologia Ruralis 52(1), 48-69. DOI: 10.1111/j.1467-9523.2011.00553.x.

[25] Neumeier, S. (2017). Social innovation in rural development: identifying the key factors of success. The Geographical Journal 183(1), 34-46. DOI: 10.1111/geoj.12180.

[26] Pato, L. (2016). Entrepreneurship, innovation and rural development the case of the Montemuro Region. In Madureira, L. Silva, P. G., Sacramento, O., Costa, A. M. \& Koehnen T., eds., Smart and Inclusive Development in Rural Areas Book of Prooceeding of the Iberian Conference on Rural Studies (pp. 431-36). Vila Real: Universidade de Trásos-Montes e Alto Douro.

[27] Pato, L., Breda, Z. \& Figueiredo, V. (2015). Women's entrepreneurship and local sustainability: the case study of a Portuguese rural initiative. Revista Turismo \& Desenvolvimento 23, 119-128.

[28] Pato, L. \& Kastenholz, E. (2017). Marketing of rural tourism - a study based on rural tourism lodgings in Portugal. Journal of Place Management and Development 10(2), 121139. DOI: 10.1108/JPMD-06-2016-0037. 
[29] Pato, L. \& Teixeira, A. A. C. (2016). Twenty years of rural entrepreneurship: a bibliometric survey. Sociologia Ruralis 56(1), 3-28. DOI: 10.1111/soru.12058.

[30] Pato, L. \& Teixeira, A. A. C. (2018). Rural Entrepreneurship: the Tale of a Rare Event. Journal os Place Management and Development 11(1), 46-59. DOI: 10.1108/JPMD-082017-0085.

[31] Pato, L. \& Teixeira, A. A. C. (2019). Are new rural ventures different from new urban ones? An exploratory analysis of businesses located in Portuguese incubators and science parks. Journal of ntrepreneurship and Public Polic, 8(4), 470-482. DOI: 10.1108/JEPP-08-2019113.

[32] Ramos, F. (2013). Annex I Portugal. In de Lima, F., Gheorginescu, O., Bouzas, N., eds., Poverty and Social Exclusion in Rural Areas (pp. 342-365). Brussels: European Commission.

[33] Rocha, P. M. (2015). Tradução Teatral O Teatro Regional da Serra do Montemuro [Master thesis]. Porto: University of Porto.

[34] Rosenbusch, N., Brinckmann, J. \& Bausch, A. (2011). Is innovation always beneficial? A meta-analysis of the relationship between innovation and performance in SMEs. Journal of Business Venturing 26(4), 441-457.

[35] Schumpeter, J. (1934). Theory of economic development: an inquiry into profits, capital, credit, interest and the business cycle. Cambridge: Harvard University Press.

[36] Stathopoulou, S., Psaltopoulos, D. \& Skuras, D. (2004). Rural entrepreneurship in Europe. A research framework and agenda. International Journal of Entrepreneurial Behavior \& Research 10(6), 404-425. DOI: 10.1108/13552550410564725.

[37] Tunney, M. (2015). Innovation in small business. Dublin: Local Enterprise Office.

[38] Woods, M. \& McDonagh, J. (2011). Rural Europe and the world: Globalization and rural development (Editorial). European Countryside 3(3), 153-163. DOI: 10.2478/v10091-0120001-z.

[39] Wortman Jr., M. S. (1990). Rural Entrepreneurship Research: An Integration into the Entrepreneurship Field. Agribusiness 6(4), 329-344. DOI: 10.1002/15206297(199007)6:4<329::AID-AGR2720060405>3.0.CO;2-N.

[40] Yin, R. (2009). Case Study Research $3^{\text {rd }}$ ed. Thousand Oaks, CA: Sage Publications.

[41] Yu, L. \& Artz, G. M. (2018). Does rural entrepreneurship pay? Small Business Economics 53(3), 647-668. DOI: 10.1007/s11187-018-0073-x.

Other sources

[42] EC (2013). Rural Development in the EU. Report 2013. Brussels: European Union.

[43] Ecorys (2010). Study on Employment, Growth and Innovation in Rural Areas. Retrieved from Rotterdan.

[44] INE (2012). Censos 2011 Resultados Definitivos Centro. Lisboa: INE.

[45] OECD (2006). The new rural paradigm policies and governance. Paris: OECD.

[46] OECD \& Eurostat (2005). OSLO Manual Guidelines for collecting and interpreting innovation data: OECD.

[47] OECD/Eurostat (2018). Oslo Mannual 2018 Guidelines for collecting, reporting and using data innovation 4th edition. Paris: OECD/Eurostat.

[48] Strano, A., Hudson, T., Redman, M., Hegarty, M., O'Hara, E., Buffet, C., . . Gardner, S. (2012). EU Rural Review No. 10, Rural Entrepreneurship: European Union. Retrieved from: https://enrd.ec.europa.eu/sites/enrd/files/ED5808AC-994A-47AD-928F-0D3088716910.pdf. 